\title{
THE IMPACT OF EMPOWERMENT AND QUALITY CULTURE ON JOB SATISFACTION
}

\author{
*Hakan KİTAPÇI \\ **Metin ATEŞ \\ *Sultan Süleyman ÖKTEN \\ *Gebze Institute of Technology, Turkey \\ ***Marmara University, Turkey
}

\begin{abstract}
The purpose of this study is to examine and compare the effects of dimensions empowerment and quality culture on job satisfaction. Data obtained from 333 employees in private Sector Company in Turkey was used to examine the hypothesized relationships among study variables. Principal factors with Varimax rotation were used for each variable to demonstrate the factor structure. We used the Cronbach's Alpha to estimate reliability scales. Then data were analyzed by correlation analysis and separate regression models. The results revealed that three dimensions of perceptions of empowerment are positively and significantly related to quality culture. The results also suggested that, one of the dimensions of empowerment and quality culture are positively and significantly related to job satisfaction.
\end{abstract}

Keywords: Empowerment, Quality Culture, Job Satisfaction

\section{Introduction}

Total Quality culture has enabled self managing teams, free information sharing between managers and employees and feedback. Employees have been included more in decision-making mechanism and they have acquired more opportunities in reaching the organizational resources easily and controlling them to attain their goals. The efforts of continuous education and improvements have become more crucial in order to develop employees' knowledge and experiences. Empowerment could be applied more easily by satisfying many requirements of the concept of empowerment. The concept of empowerment, studied as a motivational phenomenon, has been frequently related to the terms like job satisfaction in the literature (Ugboro and Obeng, 2000, Liden and Sparrowe, 2000, Osborne, 2002, Bordin, Bartram and Casimir, 2007). The dimensions of empowerment and its impact on quality culture could enable managers aiming to applying empowerment to motivate employees more effectively while solving quality problems.

\section{Empowerment}

The concept of Empowerment is a term beyond "distributing responsibility", "participative management" or another definition of management. Empowering employees enable them to become more powerful (Saeman, 1992, s.189). However, this reinforcement does not mean strengthening in organization hierarchy or in a material sense. It is rather strengthening through personal development, 
making the individual more informed, more self confidence, triggering their ability to establish more constructive and good relations and enabling them to create their own environments

\section{The Relationship Between The Dimensions Of Empowerment And Job Satisfaction}

Successful Total Quality Management programs have revealed that empowerment increases level of job satisfaction, since easier accessibility to information related to the strategies, values and mission of organizations has encouraged individuals to involve in the process of total quality process and thus, level of job satisfaction could be enhanced (Ugboro and Obeng, 2000, p.254). Another finding asserted that empowerment backed up job satisfaction through employee involvement, lower organizational levels communication, convenience of providing related information about the job requirements , promotion opportunities, development opportunities and convenience of the related information about the organization's values, vision and strategies (Ugboro and Obeng, 2000, s.263). The reward and identification systems of the organization, adaptation to a quality culture and continuous improvement-oriented education and improvement programs as components of empowerment have positive impacts on job satisfaction (Ugboro and Obeng, 2000, s.265). Thomas and Dunkerly claimed in their study conducted in England that lower levels of empowerment led to decreases in the level of job satisfaction. Meaning, being one of the four components of empowerment, has been proven as the most related dimension to job satisfaction according to the study carried out by Liden et $\mathrm{al}(2000)$. Furthermore, they have asserted that the other three dimensions have also positive effects on job satisfaction. Through their study, they have revealed that employees have experienced more job satisfaction when they could involve more in decision making process. Their study has also showed that individuals having more control power and autonomy could be more pleased in terms of their jobs since the individuals since they could adopt the successes much more. Lastly, individuals having self-efficacy, self confidence for achieving something, have a higher level of job satisfaction when compared to the ones experiencing the fear of failure (Liden and Sparrowe, 2000, s.410). Herzberg, Mausner and Snyderman (1950) noted that one's job satisfaction level depended on the meaningful job requirements and the opportunities of recognition. Hackman and Oldham has argued that job meaningfulness is a crucial determinant of job satisfaction. Employees perceiving their jobs important and valuable have higher levels of job satisfaction (Osborne, 2002, p.45). The study of Spreitzer conducted in two organizations revealed that the "meaning" dimension of empowerment was related to job satisfaction. Bordin, Bertram and Casimir acknowledged job satisfaction as one of the most significant outcomes in their study. According to their research, the meaning dimension of empowerment is crucial for job satisfaction as individuals could only be satisfied when they feel that they are subjected to a meaningful job (Spreitzer, 1997). Spreitzer also asserted that the autonomy dimension of empowerment is a psychological need and this dimension provides internal motivation. Related to the effect dimension of empowerment Liden (2000) stated: "Individuals perceive themselves as the part of the job when they believe that they could affect the work outcomes; thus, they could be more satisfied". In accordance with these arguments, individuals having the feeling of self efficacy have acquired more satisfaction (Bordin, Bartram and Casimir, 2007, s.37). Ugboro and Obeng claimed increased level of job satisfaction thanks to empowerment could facilitate top management efforts and thereby employees could become more committed to customer satisfaction, one of the main goals of Total Quality Culture (Ugboro and Obeng, 2000, s.247). 


\section{The Relationship Between Empowerment And Quality Culture}

In Total Quality Management Literature, employee involvement and empowerment are defined as the critic elements of Total Quality Management Program. Lawler (1994) identified empowerment as one of the most significant principle. Thomas and Velthouse (1990) defined empowerment as a unique task motivation reflecting individuals' orientation towards their job and role and coming out through four cognitive concepts. In this study, intrinsic task motivation is accepted as the positive experiences acquired thanks to a motivating and satisfying job. In harmony with McCleland's claims, managers having the perception of quality culture could enable individuals to perceive problems more quickly and reach the necessary resources more easily by means of the synergy supported by collaboration through applying personnel empowerment (McClelland, 1975).

Figure 1 Theoretical Research Moel

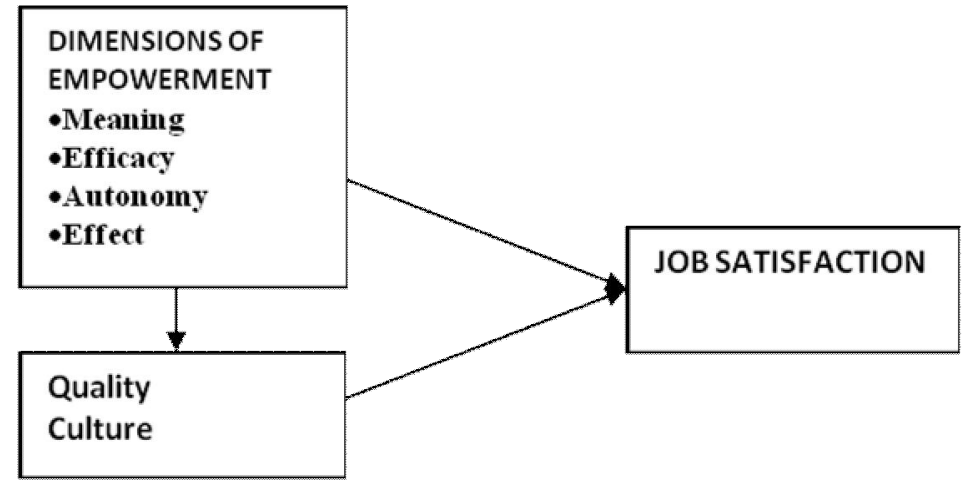

\section{Methodology And Findings}

\section{Measures, Sample, Demographic Characteristics}

The questions related to the dimensions of empowerment have been taken from the study of Spreitzer (1995), The quality culture questions are constructed by means of Manley's(1998) study and Detert, Schroeder Cudeck's (2003) study and lastly, the questions about job satisfaction are taken from Schwepker's(2001) study. In this study, all items were measured on a five point Likerttype scale where 1 = strongly disagree and $5=$ strongly agree.

The data for this study were collected from Private Sector Company. The questionnaire was answered by 343 employees, ten of them were excluded and totally 333 questionnaires are analyzed. SPSS 10.0 was used in data analysis. The analysis are respectively the demographic characteristics of the employees answering the questionnaires and frequency tables, factor analysis, reliability tests, correlation analysis including means and standard deviations and regression analysis to test the research hypothesis. 73 percent of the employees answering the questionnaire were male, 53 percent were married, age average is $27(\sigma=5,3)$ and 49 percent of them graduated from a university (Table $1)$. 
Table 1: Demographics of respondents

\begin{tabular}{lcclcc}
\hline & $N$ & $\%$ & & $N$ & $\%$ \\
\hline Marital status & & & Gender & & \\
Single & 138 & 41 & Male & 244 & 73 \\
Married & 176 & 53 & Female & 87 & 26 \\
& & & & & \\
Education & & & Position & & \\
Elementary & 217 & 44 & Blue-collar worker & 159 & 48 \\
College & 95 & 19 & Office worker & 119 & 36 \\
University & 245 & 49 & Middle- level manager & 53 & 16 \\
Graduate level & 34 & 7 & & & \\
\hline
\end{tabular}

\section{Factor Analysis}

All scale items were submitted to exploratory factor analysis the best fit of the data was obtained with a principal factor analysis with a varimax rotation. While applying factor analysis, independent and dependent variables are analyzed together, the dimensions of empowerment, job satisfaction and quality culture are included in one factor analysis at once. The results of factor analysis and eigenvalues are shown in the tables below 
Table 2: Factor Loadings and Eigenvalues of Variables

\begin{tabular}{|c|c|c|c|c|c|c|}
\hline Item Number & Quality Culture & Job Satisfaction & Impact & Competence & Meaning & Self-Determination \\
\hline 1 & 0,631 & & & & & \\
\hline 2 & 0,693 & & & & & \\
\hline 3 & 0,694 & & & & & \\
\hline 4 & 0,719 & & & & & \\
\hline 5 & 0,428 & & & & & \\
\hline 6 & 0,714 & & & & & \\
\hline 7 & 0,753 & & & & & \\
\hline 8 & 0,706 & & & & & \\
\hline 9 & 0,415 & & & & & \\
\hline 10 & 0,646 & & & & & \\
\hline 11 & 0,674 & & & & & \\
\hline 12 & 0,631 & & & & & \\
\hline 13 & & 0,711 & & & & \\
\hline 14 & & 0,662 & & & & \\
\hline 15 & & 0,807 & & & & \\
\hline 16 & & 0,806 & & & & \\
\hline 17 & & 0,708 & & & & \\
\hline 18 & & & 0,833 & & & \\
\hline 19 & & & 0,871 & & & \\
\hline 20 & & & 0,857 & & & \\
\hline 21 & & & & 0,828 & & \\
\hline 22 & & & & 0,876 & & \\
\hline 23 & & & & 0,785 & & \\
\hline 24 & & & & & 0,807 & \\
\hline 25 & & & & & 0,834 & \\
\hline 26 & & & & & 0,718 & \\
\hline 27 & & & & & & 0,748 \\
\hline 28 & & & & & & 0,775 \\
\hline 29 & & & & & & 0,772 \\
\hline \multirow[b]{2}{*}{ Component } & \multicolumn{3}{|c|}{ Initial Eigenvalues } & \multicolumn{3}{|c|}{ Rotation Sums of Squared Loadings } \\
\hline & Total & $\begin{array}{c}\% \text { of } \\
\text { Variance } \\
\end{array}$ & Cumulative \% & Total & $\%$ of Variance & Cumulative \% \\
\hline Quality Culture & 8,41 & 29 & 29 & 5,488 & 18,923 & 18,923 \\
\hline Job Satisfaction & 3,102 & 10,695 & 39,695 & 3,288 & 11,337 & 30,26 \\
\hline Impact & 2,471 & 8,52 & 48,216 & 2,913 & 10,044 & 40,304 \\
\hline Competence & 1,787 & 6,162 & 54,378 & 2,352 & 8,11 & 48,414 \\
\hline Meaning & 1,411 & 4,865 & 59,243 & 2,209 & 7,616 & 56,03 \\
\hline Self-Determination & 1,182 & 4,075 & 63,318 & 2,113 & 7,288 & 63,318 \\
\hline
\end{tabular}

\section{The Correlation Coefficients, Means, Alphas And Standard Deviation Values of The Variables}

Reliability, in short, is the result of the internal consistency considering the average relationships among the questions included in a variable (Kerlinger, 1986). Table 3 indicates that alpha values are found between 0,77 and 0,93 and this result shows that the variables have internal consistency. In 
other words, according to Cronbach alpha 0,70 coefficient is sufficient for internal consistency. Means, standard deviations, reliabilities, and correlations among all scales used in the analyses are shown in Table 3.

Table 3: The Correlations, Means, Alphas and Standard Deviations belong to the variables

\begin{tabular}{|l|c|c|c|c|c|c|c|c|}
\hline & $\boldsymbol{\alpha}$ & $\boldsymbol{\mu}$ & $\boldsymbol{\sigma}$ & $\begin{array}{c}\text { Job } \\
\text { Satisfaction }\end{array}$ & Meaning & Competence & $\begin{array}{c}\text { Self- } \\
\text { determination }\end{array}$ & Impact \\
\hline $\begin{array}{l}\text { Job } \\
\text { Satisfaction }\end{array}$ & 0,85 & 3,67 &, 87 & & & & & \\
\hline Meaning & 0,80 & 3,87 &, 82 &, $344(* *)$ & & & & \\
\hline Competence & 0,82 & 4,24 &, 67 &, $146(* *)$ &, $372(* *)$ & & & \\
\hline $\begin{array}{l}\text { Self- } \\
\text { determination }\end{array}$ & 0,77 & 3,81 &, 79 &, $201(* *)$ &, $259(* *)$ &, $303(* *)$ & & \\
\hline Impact & 0,92 & 3,24 & 1,03 &, $251(* *)$ &, $169(* *)$ &, 009 &, $406(* *)$ &, $302(* *)$ \\
\hline $\begin{array}{l}\text { Quality } \\
\text { Culture }\end{array}$ & 0,93 & 3,67 &, 79 &, $487(* *)$ &, $303(* *)$ &, $097(*)$ &, $443(* *)$ \\
\hline
\end{tabular}

$* P<0,05 ; * * P<0,01$

\section{Regression Analysis}

We tested the hypotheses with separate multiple regression analyses. The first analysis included meaning, efficacy, autonomy and effect as independents. The second regression model was developed to test the effects of these dimensions of empowerment quality culture. The third model included dimensions of empowerment and quality culture as independent variables. As seen below, the effects of dimensions of empowerment on job satisfaction and quality culture were tested with three multiple regression models and all models were found statistically significant $(\mathrm{p}<0.01)$. We predicted that higher scores on measures of perceptions of empowerment would be related to job satisfaction and quality culture. In model 1, meaning was related to job satisfaction. In model 2, meaning, self-determination and impact were strongly related to quality culture. Third model examined the effects of dimensions of empowerment and quality culture on job satisfaction and revealed that meaning and quality culture are positively related to job satisfaction $(\mathrm{p}<0.01)$ (Table 4). 
Table 4: Regression Models

\begin{tabular}{|c|c|c|c|c|c|c|c|c|c|}
\hline & \multicolumn{3}{|c|}{$\begin{array}{c}\text { Model 1 } \\
\text { (Job Satisfaction) }\end{array}$} & \multicolumn{3}{|c|}{$\begin{array}{c}\text { Model 2 } \\
\text { (Quality Culture) }\end{array}$} & \multicolumn{3}{|c|}{$\begin{array}{c}\text { Model 3 } \\
\text { (Job Satisfaction) }\end{array}$} \\
\hline & $\beta$ & $t$ & Sig. & $\beta$ & $t$ & Sig. & $\beta$ & $t$ & Sig. \\
\hline Meaning & 0,177 & 2,902 &, $004 * *$ & 0,122 & 2,082 & ,038* & 0,15 & 2,487 & ,013* \\
\hline Competence & 0,107 & 1,677 & 0,094 & 0,112 & 1,839 & 0,067 & & 1,298 & \\
\hline $\begin{array}{l}\text { Self- } \\
\text { determina- } \\
\text { tion }\end{array}$ & 0,018 & 0,293 & 0,77 & 0,125 & 2,122 & ,035* & 0,081 & $-0,174$ & 0,195 \\
\hline Impact & 0,072 & 1,258 & 0,209 & 0,236 & 4,323 &, $000 * *$ & 0,018 & 0,311 & 0,756 \\
\hline $\begin{array}{l}\text { Quality Cul- } \\
\text { ture }\end{array}$ & - & - & - & - & - & - & 0,229 & 4,054 &, $000 * *$ \\
\hline & \multicolumn{3}{|c|}{$\boldsymbol{F}=6,335$} & \multicolumn{3}{|c|}{$\boldsymbol{F}=14,698$} & \multicolumn{3}{|c|}{$\mathbf{F}=8,594$} \\
\hline & \multicolumn{3}{|c|}{$\boldsymbol{R}^{2}=, 072$} & \multicolumn{3}{|c|}{$\boldsymbol{R}^{2}=, 152$} & \multicolumn{3}{|c|}{$\boldsymbol{R}^{2}=, 116$} \\
\hline & \multicolumn{3}{|c|}{ Sig. $=, 000$} & \multicolumn{3}{|c|}{ Sig. $=, 000$} & \multicolumn{3}{|c|}{ Sig $=, 000^{*}$} \\
\hline
\end{tabular}

$* P<0,05$;

$* * P<0,01$

Model 2 revealed that meaning $(\beta=0.122$, $p<0.05)$, self-determination $(\beta=0.125, \mathrm{p}<0.05)$ and impact $(\beta=0.236, p<0.01)$ are positively related to quality culture however it is found that impact is more strongly related to quality culture than the others. After quality culture was added to the model in model 3, meaning $(\beta=0.150, \mathrm{p}<0.05)$ and quality culture $(\beta=0.428, \mathrm{p}<0.01)$ were still significant. Besides Self-determination and Impact lost its statistical significance (see Table 4). This implies a mediation relationship (Baron and Kenny, 1986) that the relationship between dimensions of empowerment and job satisfaction is fully mediated by quality culture. Thus based on the regression analysis, the following empirical model has been developed (Figure 2).

Figure 2: Empirical research model

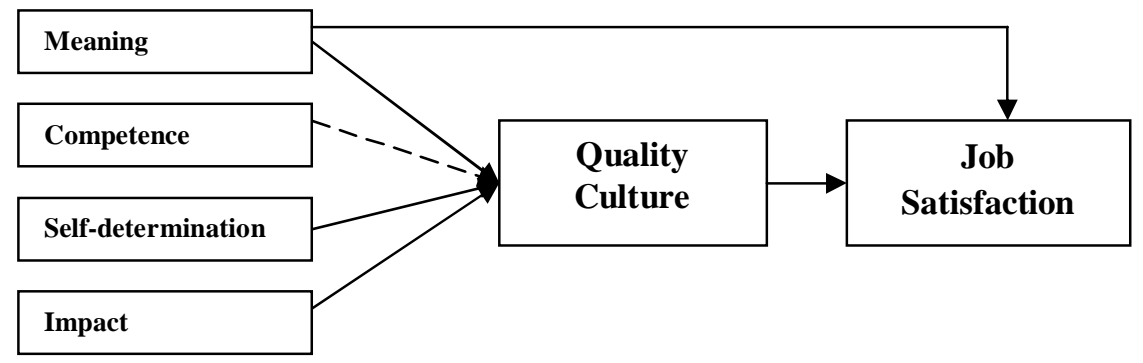

\section{Discussion And Conclusion}

This study is carried out to reveal the effects of the dimensions of empowerment on job satisfaction and the changes the quality culture leading on these effects.

According to our analysis, a positive relationship is found between the meaning dimension of empowerment and job satisfaction. In empirical studies, meaning has received strong support as being positively associated with job satisfaction. In Spreitzer and colleagues (1997) study, meaning was 
related to work satisfaction and explained the most variance in work satisfaction (Spreitzer et al., 1997). Carless (2004) used a sample of customer service employees to study empowerment and job satisfaction. She found meaning to be significantly related to present job satisfaction. Liden and colleagues (2000) studied employees in lower levels of several major divisions of a large service organization. They also found the meaning cognition of psychological empowerment to have a significant relationship with work (Liden et al., 2000). Meaning can be defined as a consistency between an individual's beliefs, values and behaviors and the requirements of the job. This consistency is the significance of the job for the individual. The more harmony between the employee's beliefs, values and the requirements of the job has perceived, the more importance is given to the job by the employee. In other words, the consistency between the requirements of the conducted work and the individual's beliefs, values and behaviors is the indicator of the meaningfulness of the job for the employee (Spreitzer, 1995).

The dimensions of empowerment which was meaning, self-determination and impact have impacts on quality culture. The sense of quality culture encourages empowerment of employees to improve work processes better and satisfy costumer efficiently.

At first, individuals should believe that they are important for the organization to feel themselves effective. If the top management does not give much responsibility to the employees and provide them the opportunities to carry out their own works, they overshadow the emergence of individuals' creativity. Taking responsibility for conducting one's own job increases the individual's self confidence. The monopoly of decision making mechanisms owned by managers decreases the employee's motivation level. The individual's creativity and innovativeness could be increased through expressing themselves without hesitation related to the decisions about the work. In Japanese culture, being the leader in the quality applications, individuals decide on their own related to their own work processes and they have the required authorities to improve the quality and performance (Zhao, 1993). Especially, the meaning and effect dimensions of the empowerment have impacts on job satisfaction, the employees could adopt the works and they really effect the department while realizing the work and therefore their satisfaction levels are increased.

Empowerment is known to be one of the most crucial principles of Total Quality Management. That's why, empowerment is expected to be more applicable in the organizations where Total quality management prevails. Among the dimensions of the empowerment, meaning, self-determination and impact have impacts on quality culture. These dimensions foster a better perception of quality culture (Table 4). The strongest relationships were found between quality culture and job satisfaction. The relationship between quality culture and job satisfaction is consistent with the Elçi et.al., (2007). Furthermore, recent research also suggests a strong positive relationship between, quality culture and employees' job satisfaction (Ugboro \& Obeng, 2000). Blackburn \& Rosen (1993) reported that organizations with successful TQM programs, especially those that have won the Malcolm Baldrige Quality Award, have employees with higher job satisfaction. Moreover, research yielded those highly motivated employees who are satisfied with their jobs showed higher performance in their jobs as a result of their perception of the emphasis that the organizational culture places on quality (Schlesinger \& Heskett, 1991; Schlesinger \& Zomitsky, 1991). Managers should aim to establish more flexible working environments instead of forced imperatives and enable the employees to acquire more responsibility related to their own works. Thus, individuals could adopt their jobs better and become more committed to the organization. 
The limitations of this study include the use of a very specific sample of employees. It might be the case that the findings of this study may not be generalisable to employees in different industries. In spite of these limitations, the results of this study are present. First, the findings of this study have shown that meaning, self-determination and impact are positively related to quality culture. Second, the findings reveal that quality culture and meaning can increase job satisfaction. 


\section{REFERENCES}

Baron, R. M., and Kenny, D. A. (1986). The moderator-mediator distinction in social psychological research: conceptual, strategic, and statistical considerations. Journal of Personality and Social Psychology, 51, pp.1173-1182.

Blackburn, R. \& Rosen, B. (1993) Total quality and human resources management: lessons learned from Baldridge award-winning companies, Academy of Management Executive, 7(3), pp. 49 -66 .

Bordin C., Bartram T., Casimir G., (2007) "The antecedents and consequences of psychological empowerment among Singaporean IT employees", Management Research News, Vol.30, No.1, p.37

Carless, S. A. (2004). Does psychological empowerment mediate the relationship between psychological climate and job satisfaction? Journal of Business and Psychology, 18(4), 405-425.

Detert, J.R., Schroeder, R.G., Cudeck, R., (2003), "The measurement of Quality Management Culture in Schools: Development and Validation of the SQMCS", Journal of Operation Management, Vol.21, pp.307-328

Elçi, M., Kitapçý, H., \& Ertürk, A., (2007) Effects of Quality Culture and Corporate Ethical Values on Employee Work Attitudes and Job Performance in Turkey: An Integrative Approach, Total Quality Management, Vol. 18, No. 3, pp.285-302.

Kerlinger, F.N., (1986). Foundations of Behavioral Research (3rd ed.). Forth Worth, TX: Holt Rinehart and Winston, Inc.

Lawler E. E., (1994), "Total Quality Management and Employee Involvement: Are They Compatible?", Academy of Management Executive 8 (1), pp.68-76.

Liden, R.C., Wayne, S.J. \& Sparrowe, R.T.(2000), “An Examination of the Mediating Role of Psychological Empowerment on the Relations Between the Job, Interpersonal Relationships, and Work Outcomes", Journal of Applied Psychology, Vol:85 No:3, pp.407-416

Manley, J.E., (1998) "Symbol, Ritual, and Doctrine: The Cultural 'Tool Kit' of TQM”, Journal of Quality Management, Vol.3, No:2, pp.175-191

McClelland, D. C. (1975). Power: The inner experience. New York: Irvington

Osborne, J.S., Components of Empowerment and How They Differentially Relate to Employee Job Satisfaction, Organizational Commitment, and Intent to Leave the Job, Peabody College of Vanderbilt University, May 2002

Saeman, R. (1992), "The environment and The Need for New Technology: Empowerment and Ethical Values", The Colombia Journal of World Business, Vol.17,Fall-Winter, pp.186-193

Schlesinger, L. A. \& Heskett, J. (1991) Breaking the cycle of failure in services, Sloan Management Review, 32(3), pp. 17-28.

Schlesinger, L. A. \& Zomitsky, J. (1991) Job satisfaction, service capability and customer satisfaction: an examination of linkages and management implications, Human Resource Planning, 14(2), pp. 141-149. 
Schwepker, C.H. (2001), "Ethical Climate's relationship to job satisfaction, organizational commitment, and turnover intention in the salesforce", Journal of Business Research, Vol.54, pp.39-52

Spreitzer, G. M., Kizilos, M. A., \& Nason, S. W. (1997). A Dimensional Analysis of the Relationship Between Psychological Empowerment and Effectiveness, Satisfaction, and Strain. Journal of Management, 23(5), pp.679-705.

Spreitzer, Gretchen M. (1995), "Psychological Empowerment in the Workplace: Dimensions, Measurement, and Validation", The Academy of Management Journal, Vol.38, No.5

Thomas, K.W. and Velthouse, B.A. (1990), "Cognitive Elements of Empowerment: an 'interpretive model' of intrinsic task motivation" Academy of Management Review 15, pp.666-681.

Ugboro, I. O. \& Obeng, K. (2000) Top management leadership, employee empowerment, job satisfaction, and customer satisfaction in TQM organizations: an empirical study, Journal of Quality Management, 5, pp.247-272.

Ugboro, Isaiah O. \& Obeng, Kofi (2000) “Top management leadership, employee empowerment, job satisfaction, and customer satisfaction in TQM organizations: an empirical study", Journal of Quality Management,5, pp.247-272

Zhao B., (1993), “How Do Japanese Manage Total Quality?” Association of Business Studies, Best Paper Proceedings, pp.153-160. 